\title{
PENGEMBANGAN BUKU SUPLEMEN KIMIA BERBASIS SAINS TEKNOLOGI MASYARAKATPADA MATERI KIMIA POLIMER
}

\author{
Mira Rizki ${ }^{1}$, Dedi Irwandi ${ }^{1}$, Evi Sapinatul Bahriah ${ }^{1, *}$ \\ 1 Pendidikan Kimia Fakultas Ilmu Tarbiyah dan Keguruan UIN Syarif Hidayatullah \\ Jl. Ir. H. Juanda No. 95 Ciputat Jakarta 15412 Indonesia \\ e-mail:3evi@uinjkt.ac.id
}

\begin{abstract}
ABSTRAK
Penelitian ini bertujuan untuk menghasilkan buku suplemen kimia berbasis sains teknologi mayarakat (STM) pada materi kimia polimer serta mengetahui respon guru dan siswa terhadap buku tersebut. Metode penelitian yang digunakan adalah deskriptif kualitatif melalui tiga tahap yaitu tahap perancangan, produk, dan evaluasi. Data yang diperoleh dianalisis secara deskriptif. Pada tahap persiapan dihasilkan indikator buku suplemen yang telah diintegrasikan dengan lima ranah STM untuk dijadikan acuan dalam mengembangkan buku suplemen. Pada tahap produk dihasilkan buku suplemen yang telah divalidasi oleh 3 orang dosen. Tahap evaluasi buku suplemen diuji cobakan pada 3 orang guru kimia dan 41 orang siswa kelas XII MIA 4 SMAN 3 Karawang. Produk divalidasi dan direspon berdasarkan aspek kelayakan isi, sajian, bahasa, dan grafika. Hasil penelitian menunjukkan bahwa buku suplemen yang dikembangkan memiliki karakteristik penyajian materi antara konsep dan aplikasi serta dampaknya disajikan secara seimbang dengan mengintegrasikan ranah sains teknologi masyarakat agar pembaca lebih peduli mengenai lingkungan tempat tinggalnya sehingga pembaca akan merasakan bahwa ilmu kimia berhubungan erat dengan kehidupannya sehari-hari. Hasil uji coba terbatas mendapatkan total skor respon guru sebesar $80,61 \%$ termasuk dalam kategori layak dengan predikat baik. Hasil respon siswa mendapatkan total skor sebesar $82,01 \%$ termasuk dalam kategori layak dengan predikat baik.
\end{abstract}

Kata kunci: Buku Suplemen; Sains Teknologi Masyarakat; Kimia Polimer; Deskriptif.

\section{ABSTRACT}

The aims of the research were to produce a science society technology (STS) based chemistry supplementary books on polymer chemistry and to know the teacher and students' response about the book. The research method was descriptive qualitative including three phases; planning, producing, and evaluating. Then, the data were analyzed descriptively. In planning phase, the result of supplement book indicator was integrated within five STM domains in to become a reference in developing the next supplement book. In producing phase, there were three experts who have been validated the data of supplement book. In evaluating phase, the supplement book was examined by three chemistry teacher and forty-one students XII MIA 4 of SMAN 3 Karawang. The product had been validated and responded based on reasonable content, presentation, language, and graphic arts. The result of the research shows the supplement book which has been developed had characteristics in presenting the material between the concept and the application, also the impact itself was presented equally within integrating the domain of science technology and society, so that the readers will feel there was a relation between chemistry and their daily activity environment. The result of limited trial was the teacher's responses score $80.61 \%$ including to a proper category with good predicate. The result from the students' response was 82.01 including to a proper category with good predicate.

Keywords: Book Suplement; Science Technology Society; Polymer Chemistry; Descriptive.

DOI: http://dx.doi.org/10.15575/jta.v1i2.1233 


\section{PENDAHULUAN}

UU No 20 Tahun 2003 tentang sistem Pendidikan Nasional, menyatakan bahwa: "Pendidikan adalah usaha sadar dan terencana untuk mewujudkan suasana belajar dan proses pembelajaran agar peserta didik secara aktif mengembangkan potensi dirinya untuk memiliki kekuatan spiritual keagamaan, pengendalian diri, kepribadian, kecerdasan, akhlak mulia, serta keterampilan yang diperlukan dirinya, masyarakat, bangsa dan negara.

Dalam UU tersebut juga disebutkan bahwa tujuan pendidikan nasional adalah "untuk berkembangnya potensi peserta didik agar menjadi manusia yang beriman dan bertakwa kepada Tuhan Yang Maha Esa, berakhlak mulia, sehat, berilmu, cakap, kreatif, mandiri, dan menjadi warga negara yang demokratis serta bertanggung jawab" (UU No. 20 Tahun 2003). Oleh karena itupendidikan dianggap memberikan jaminan bagi peningkatan taraf hidup dan pendakian ditangga sosial (Tirtaraharja, 2008, hal. 245). Sehingga pendidikan merupakan suatu hal yang penting untuk menentukan kemajuan suatu bangsa. Pendidikan akan menghasilkan sumber daya manusia yang berkualitas dari segi kognitif, spiritual, dan keterampilan. Jika output dari proses pendidikan ini buruk, maka dapat dikatakan pula bangsa tersebut gagal.

Proses pembelajaran adalah proses penyampaian informasi melalui media tertentu kepada penerima informasi. Terkadang terjadi kegagalan dalam proses penyampaian informasi tersebut. Kegagalan tersebut terjadi karena beberapa faktor diantaranya kemampuan pedagodi pendidik, keutuhan pencapaian sasaran, kurikulum, pendayagunaan teknologi pendidikan (bahan ajar), sarana dan prasarana belajar, dan sistem evaluasi yang diterapkan (Tirtaraharja, 2008, hal. 234). Kurikulum merupakan suatu pedoman pendidikan atau pengajaran. Kurikulum yang digunakan di Indonesia telah beberapa kali mengalami perubahan. Perubahan ini berdampak pada tidak terpakainya lagi buku paket siswa dan buku pegangan guru beserta perangkat lainnya karena harus diganti dengan buku-buku yang baru untuk menyesuaikan kurikulum yang sedang digunakan (Tirtaraharja, 2008, hal. 236).

Buku sebagai salah satu sumber informasi, disadari penting peranannya dalam proses pendidikan. Kebutuhan akan buku semakin terasa di daerah-daerah yang karena berbagai hal belum memiliki sumber informasi lainnya seperti media elektronik (Paembonan, 1990, hal. 23). Dalam Peraturan Pemerintah nomor 16 tahun 2007 tentang standar kompetensi guru yaitu bahwa guru diharapkan mampu mengembangkan materi pembelajaran secara kreatif. Berdasarkan Peraturan Pemerintah tersebut jelas bahwa guru diharapkan mampu mengembangkan buku ajar sebagai salah satu bahan ajar dalam pembelajaran. Namun permasalahan yang terjadi sekarang ini masih banyak guru yang kesulitan dalam mengembangkan bahan ajar dan tergantung pada bahan ajar yang sudah tersedia. Sedangkan kebutuhan siswa akan ilmu pengetahuan tidak cukup hanya bersumber pada satu buku saja. Dalam pendidikan formal, buku yang baik memperkaya dan memperluas wawasan pengetahuan dan pengalaman peserta didik, maka di luar pendidikan formal, buku merupakan sumber informasi utama (Paembonan, 1990, hal. 23).

Menteri Pendidikan Nasional Nomor 2 tahun 2008 pasal 6 (2) menyatakan bahwa selain buku teks pelajaran, pendidik dapat menggunakan buku panduan pendidik, buku pengayaan, dan buku referensi dalam proses pembelajaran. Berdasarkan hasil wawancara, beberapa guru masih ada yang belum tahu tentang buku suplemen atau buku pengayaan, selain itu ada yang mengira bahwa buku suplemen berisi latihan soalsoal. Buku pelajaran pelengkap atau pengayaan dapat dikatakan buku suplemen. 
Hal ini didasarkan pada pengertian buku suplemen menurut Kurniasari (2014, hal. 463) buku suplemen adalah buku yang dipergunakan untuk mendampingi atau melengkapi buku utama. Pengertian ini sejalan dengan Menteri Pendidian Nasional Nomor 2 Tahun 2008 pasal 1 ayat 5 bahwa "buku pengayaan adalah buku yang memuat materi yang dapat memperkaya buku teks pendidikan dasar, menengah, dan perguruan tinggi". Buku suplemen merupakan buku yang dapat memperkaya dan meningkatkan penguasaan ipteks, keterampilan, dan membentuk kepribadian peserta didik, pendidik, pengelola pendidikan, dan masyarakat lainnya. Buku jenis ini tidak semata-mata dimaksudkan hanya untuk peserta didik namun dapat pula digunakan oleh pihak lain atau masyarakat pada umumnya (Pusat Perbukuan, 2008, hal 8). Buku suplemen dibutuhkan untuk menambah kreativitas dan pengetahuan siswa. Dalam pembelajaran, dibutuhkan banyak sumber agar pengetahuan anak berkembang, tidak hanya aspek kognitifnya tapi juga aplikasi dan penerapannya.

Bahan pembelajaran pada buku suplemen yang di buat harus lebih aplikatif, jadi dapat lebih meningkatkan minat baca siswa, karena tidak hanya sekedar konsep yang mereka dapatkan tapi kegunaan untuk kehidupannya juga. Buku suplemen tersebut harus mengikuti perkembangan trend. Materi yang disuguhkan di jelaskan secara jelas dan luas dan bisa mengungkapkan masalah yang terjadi di masyarakat (Saefudin, 2015). Bahasa yang digunakan mudah dipahami siswa, gambar yang menarik dan berwarna sehingga anak tertarik untuk membaca (Nurlaelasari, 2015). Sesuai penelitian yang dilakukan oleh Kurniasari (2014, hal 463) bahwa "diperlukan suatu inovasi bahan ajar yang mudah dipahami dengan penggunaan kata-kata sederhana tetapi tetap tidak mengesampingkan makna yang sesungguhnya serta menampilkan ilustrasiilustrasi yang menarik."

Sehubungan dengan perubahan kurikulum, saat ini Indonesia sedang menerapkan Kurikulum 2013. Salah satu karakteristik
Kurikulum 2013 adalah siswa yang telah belajar di sekolahnya harus bisa mengembangkan sikap, pengetahuan, dan keterampilan serta menerapkannya dalam berbagai situasi di sekolah dan masyarakat (Permendikbud RI No. 69, 2013, hal. 3). Masalah pokok pendidikan saat ini adalah bagaimana pendidikan dapat membekali peserta didik dengan segala macam ketampilan yang mantap untuk dapat mengaplikasikan ilmu yang mereka terima selama pendidikannya sehingga berguna bagi masyarakat sekitar. Saat ini pembelajaran dan buku yang tersedia di sekolah hanya menjelaskan bagian kognitifnya saja yang dapat terpenuhi namun untuk bagian psikomotor dan penerapan dalam kehidupan sehari-hari masih kurang (Zul, 2015). Untuk itu, diperlukan pembelajaran kimia yang memberikan pemahaman bahwa segala sesuatu yang kita hadapi dalam kehidupan ini mengandung aspek sains, lingkungan, teknologi, dan masyarakat sebagai satu kesatuan serta saling mempengaruhi secara timbal balik (Nugraheni, 2013, hal. 34).

Pembelajaran Sains Teknologi Masyarakat (STM) mengaitkan pembelajaran sains dengan teknologi serta manfaatnya bagi masyarakat. Sehingga konsep yang telah dipelajari oleh peserta didik dapat bermanfaat untuk dirinya dan untuk menyelesaikan permasalahan yang terjadi di masyarakat tempat tinggalnya. Mengingat kemajuan teknologi seperti sekarang ini diharapkan manusia dapat memanfaatkan teknologi tersebut agar dapat memelihara produk teknologi dan dijadikan pedoman untuk mengatasi kesulitan yang ada. Untuk itu peserta didik diharapkan menjadi anggota masyarakat yang mampu menguasai sains dan teknologi serta memanfaatkannya bagi kesejahteraan masyarakat (Poedjiadi, 2010, hal. 96).

Ilmu kimia merupakan salah satu ilmu yang sangat erat hubungannya dengan kehidupan manusia, terutama kimia polimer yang saat ini tidak hanya berhubungan dengan material dan tidak hanya penting secara komersil, namun juga sudah menjadi bagian dari 
keseharian kita. Namun, pembelajaran mengenai kimia polimer hanya menuntut siswa untuk sekedar mengetahui teori tentang kimia polimer saja. Bahkan dalam pembelajaran di kelas XII, materi tentang kimia polimer hanya membahas mengenai jenisnya, sifatnya, dan reaksi pembentukannya. Hal ini disebabkan oleh alokasi waktu yang kurang memadai sehingga guru kesulitan untuk menjelaskan materi lebih mendalam mengenai kimia polimer karena siswa lebih difokuskan untuk persiapan menghadapi UN kelas XII dengan materi yang banyak (Zul, 2015). Buku pada materi kimia polimer umumnya hanya memuat sedikit contoh polimer untuk kehidupan sehari-hari (Teti, 2015). Buku yang telah ada hanya mencakup reaksi pembentukan polimer, penggolongan polimer, sifat fisik polimer, dampak negatif dan penanggulangannya secara umum. Padahal polimer merupakan bahan yang sering dijumpai dan akrab dengan kehidupan peserta didik. Contohnya kemasan plastik makanan, kantong belanja, tekstil untuk baju, sendok plastik, botol susu, mainan anak-anak, peralatan olahraga, dan peralatan medis. Selain itu, materi yang ada cenderung hanya membahas mengenai konsep sains tapi belum dikaitkan dengan permasalahan dalam masyarakat atau lingkungan tempat peserta didik tinggal. Hal ini bisa dilihat dari kurangnya pemahaman peserta didik dan masyarakat tentang pemakaian dan bahaya dari penggunaan kemasan pangan plastik dalam kehidupan sehari-hari. Contohnya menggunakan kembali botol kemasan minuman yang sudah dipakai, bahkan mengisi ulang botol minuman dengan air panas tanpa tahu dampak negatif bagi kesehatan. Selain itu, minimnya pengetahuan dan kesadaran peserta didik dan masyarakat mengenai penanganan limbah plastik menimbulkan masalah yang cukup meresahkan bagi lingkungan, karena limbah plastik yang kian bertambah setiap harinya menjadikan Indonesia menjadi peringkat kedua dunia sebagai penghasil sampah plastik ke Laut setelah Tiongkok (MenLHK, 2016). Hal ini menjadikan alasan bagi Kementrian Lingkungan Hidup dan Kehutanan (LHK) untuk melakukan ujicoba penerapan kebijakan kantong plastik berbayar mulai tanggal 21 Februari 2016. Oleh karena itu, peserta didik dan masyarakat membutuhkan wawasan yang lebih luas dan mendalam, bukan hanya mengenai konsepkonsep ilmu pengetahuan, tetapi ditambahkan mengenai pengaruh ilmu pengetahuan dan teknologi bagi masyarakat (Nuryanto \& Binadja, 2010, hal. 553).

Penelitian mengenai kimia polimer ini telah dilakukan oleh Hervici yang berjudul pengembangan modul kimia polimer berbasis kontekstual sebagai sumber belajar mandiri peserta didik SMA/MA kelas XII semester 2 mendapatkan hasil bahwa modul kimia polimer berbasis kontekstual yang dikembangkan layak digunakan sebagai sumber belajar mandiri bagi peserta didik kelas XII SMA/MA. Berdasarkan penilaian dari 3 orang guru kimia mendapatkan skor 99 dengan persentase keidealan $90 \%$ atau dengan kategori Baik (B). Respon 10 orang peserta didik diperoleh skor 19,6 dengan persentase keidealan sebesar 98\% atau dengan kategori Sangat Baik (SB). Penelitian ini memiliki kekurangan yaitu modul yang digunakan hanya dinilai oleh 10 peserta didik saja dan tidak diujicobakan dalam kegiatan belajar mengajar serta penelitian yang dilakukan mengenai materi kimia polimer belum banyak dilakukan (Hervici, 2013, hal. 81).

Atas dasar masalah yang diuraikan di atas, peneliti tertarik untuk mengembangkan media pembelajaran berbentuk buku suplemen berbasis sains teknologi masyarakat sebagai penunjang pembelajaran peserta didik.

\section{METODE PENELITIAN}

Proses perancangan sampai evaluasi dilakukan pada bulan Mei 2015 sampai Februari 2016. Uji coba penelitian ini dilakukan di SMA Negeri 3 Karawang kelas XII MIA 4 semester 2 tahun ajaran 2015-2016.

Metode penelitian yang digunakan adalah metode deskriptif, yaitu metode yang menganalisis data yang diperoleh berupa 
kata-kata, gambar, perilaku tidak dituangkan dalam bentuk bilangan atau angka statistik tetapi dalam bentuk kualitatif yang memilliki arti lebih kaya dari sekedar angka (Margono, 2013, hal. 39).

Objek pada penelitian ini adalah buku suplemen berbasis sains teknologi masyarakat pada materi kimia polimer. Subjek penelitian yaitu: 3 orang dosen kimia; 3 orang Guru mata pelajaran kimia; dan 41 orang Siswa kelas XII MIA 4 SMA Negeri 3 Karawang.

Pengembangan buku suplemen ini terbagi menjadi tiga tahap, yaitu: tahap perencanaan, tahap produksi, dan tahap evaluasi. Adapun instrumen penelitian yang digunakan dalam penelitian ini adalah: pedoman wawancara, studi dokumen, lembar validasi, dan angket respon.

Data lembar validasi dihitung menggunakan skala Guttman. Sedangkan data angket respon guru dan siswa yang dianalisis menggunakan skala rating scale. Analisis data dilakukan dengan memberi pemaparan gambaran mengenai situasi yang diteliti dalam bentuk uraian naratif sesuai dengan interpretasi dari hasil analisis data tersebut. Walaupun peneliti mengadakan perhitunganperhitungan statistik, maka fungsinya hanya untuk membantu analisis data kualitatif (Sanjaya, 2013, hal. 65). Data kualitatif merupakan data yang dinyatakan dalam katakata. Perhitungan statistik yang diperoleh ditabulasikan kemudian dicari presentasinya dan dianalisis menggunakan rumus(Riduwan, 2010, hal. 41). Setelah itu, diperhitungkan nilai secara keseluruhan untuk mendapatkan kesimpulan mengenai kelayakan yang berkenaan dengan semua aspek yang dinilai pada buku suplemen kimia yang dikembangkan, dengan menggunakan aturan perhitungan penilaian yang ditabulasikan dengan rumus sebagai berikut (Pusat Perbukuan, 2014, hal. 4):

Total Skor Akhir $=$ (Materi $\times$ 40\%) + (Penyajian $\times 30 \%)+($ Bahasa $\times 20 \%)+($ Grafika $x$ 10\%)
Jika skor perolehan $\geq 85$ (kategori Layak dengan predikat sangat baik); $55 \leq$ Skor $<85$ (kategori Layak dengan predikat baik); dan Skor $<55$ (kategori Tidak layak) (Pusat Perbukuan, 2014, hal. 9).

\section{HASIL DAN PEMBAHASAN}

Tahap perencanaan dilaksanakan dalam lima subtahapan yaitu analisis kebutuhan, analisis indikator/karakteristik buku suplemen, analisis KD dan indikator umum, analisis indikator buku suplemen berbasis sains teknologi masyarakat (STM), validasi indikator buku berbasis sains teknologi masyarakat, dan desain buku suplemen berbasis STM. Tahap produksi ini dikelompokkan ke dalam dua subtahapan yaitu pengembangan buku suplemen dan validasi buku suplemen.

Tahap evaluasi dilakukan untuk mengetahui respon guru dan siswa mengenai buku suplemen yang telah dikembangkan serta untuk mengetahui kelayakan buku suplemen kimia berbasis sains teknologi masyarakat pada materi kimia polimer sebagai buku pendamping yang mampu menambah wawasan kepada pembaca. Tahap evaluasi buku suplemen ini dilakukan dengan uji coba terbatas kepada 3 orang guru mata pelajaran kimia dan 41 siswa SMAN 3 Karawang dengan pengisian angket respon oleh guru dan siswa setelah membaca buku tersebut. Berikut hasil rekapitulasi angket respon guru dan siswa.

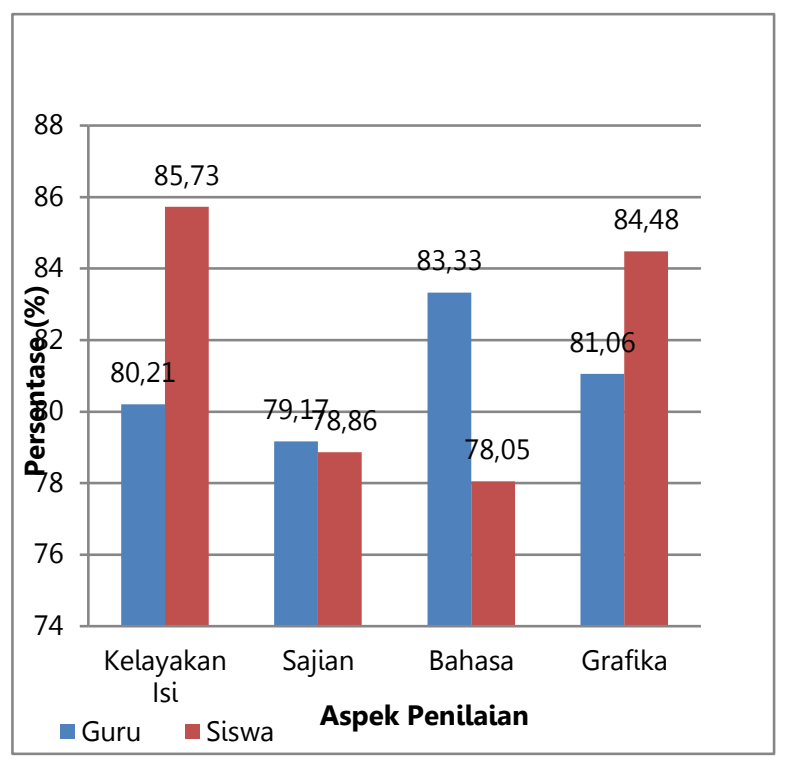




\section{Gambar 1. Persentase Rata-Rata Tiap Aspek}

Gambar 1 dapat dilihat bahwa persentase rata-rata angket tiap aspek pada guru untuk aspek kelayakan isi sebesar $80,21 \%$, aspek sajian $79,17 \%$, aspek bahasa $83,33 \%$, aspek grafika $81,06 \%$. Setiap aspek memiliki skor komponen masing-masing yaitu skor pada aspek kelayakan isi adalah $40 \%$, aspek sajian $30 \%$, aspek bahasa $20 \%$, dan aspek grafika $10 \%$. Hasil rata-rata aspek yang didapatkan kemudian dikalikan dengan skor komponen sehingga didapatkan skor akhir sebesar $80,61 \%$. Berdasarkan rubrik penilaian buku suplemen dari PusKurBuk apabila total skor akhir lebih dari 55 dan kurang dari 85 maka buku pengayaan dinyatakan layak dengan predikat baik.

Persentase rata-rata angket tiap aspek pada siswa menunjukkan hasil yang tidak jauh berbeda, untuk aspek kelayakan isi 85,73\%, aspek sajian 78,86\%, aspek bahasa $78,05 \%$, aspek grafika $84,48 \%$. Dengan menggunakan rumus yang sama pada perhitungan respon guru, maka didapatkan skor akhir sebesar 82,011\% maka termasuk kategori layak dengan predikat baik.

Data hasil perhitungan persentase respon guru diperoleh bahwa skor akhir sebesar 80,61\% termasuk kategori layak dengan predikat baik. Hasil persentase tertinggi terdapat pada aspek bahasa sebesar 83,33\% dengan kategori layak dengan predikat baik. Kategori layak pada aspek bahasa didapatkan karena penulisan yang digunakan pada buku suplemen sesuai dengan kaidah EYD yang benar. Hal ini sejalan dengan penelitian yang dilakukan Ulfah (2013, hal. 242) bahwa penggunaan bahasa yang baik disesuaikan dengan kaidah tata bahasa Indonesia dan mengacu pada Ejaan Yang Disempurnakan (EYD), bahasa yang digunakan adalah bahasa yang baku, komunikatif, dan mudah dipahami pembaca untuk mempelajari materi pelajaran. Kelayakan juga didapatkan bahwa bahasa sudah sesuai dengan sasaran pembaca dan mudah dipahami. Hal ini menunjukkan bahwa bahasa yang digunakan sudah mampu membantu pembaca dalam memahami pesan yang disampaikan dan menggunakan istilah yang umum digunakan dalam kehidupan sehari-hari (Jannah \& Dwiningsih, 2013, hal. 177).

Aspek yang tertinggi kedua adalah aspek grafika dengan rata-rata persentase aspek sebesar 82,06\% dengan kategori layak dengan predikat baik. Butir pernyataan tertinggi pada aspek grafika adalah desain buku secara keseluruhan menarik serta jenis dan ukuran huruf yang digunakan pada seluruh isi buku menarik dan konsisten dengan persentase sebesar $100 \%$. Hal ini dikarenakan materi disajikan secara menarik dan memiliki tingkat kegrafikaan yang baik serta penggunaan jenis huruf yang tidak terlalu banyak dan konsisten. Hal ini sesuai dengan pendapat (Widodo, 2008, hal. 52) bahwa konsistensi harus dipenuhi dalam hal bentuk dan huruf dari setiap halaman. Selanjutnya adalah butir pernyataan mengenai kejelasan judul buku suplemen dan ilustrasi yang digunakan memiliki persentase 83,33\% termasuk kategori layak. Hal ini sesuai dengan pendapat Sofyan (dalam Esmiyati, 2013, hal. 183) bahwa penyusunan bahan ajar perlu dilengkapi dengan ilustrasi atau gambar-gambar yang secara visual dapat memberikan gambaran nyata tentang substansi yang dipelajarinya. Selanjutnya adalah butir pernyataan mengenai cover buku yang mendapatkan persentase sebesar $75 \%$ dengan predikat baik. Hal ini menandakan bahwa cover buku sudah sesuai dengan isi buku sehingga dapat menarik minat baca dan mempermudah pembaca untuk mengetahui isi dari buku suplemen yang tercermin pada cover sesuai dengan penelitian yang dilakukan Kurniasari (2014, hal. 465). Butir pernyataan mengenai tata letak dan konsistensi penomoran memiliki persentase sebesar $66,67 \%$ dan $58,33 \%$. Hal ini dikarenakan konsep dasar dari penulis yang memang tidak menggunakan penomoran di bagian sub bab materi melainkan hanya diberi nomor pada bagian bab saja.

Aspek kelayakan isi dengan rata-rata persentase aspek sebesar 80,21\% termasuk kategori layak dengan predikat baik. Hasil persentase tertinggi adalah butir pernyataan 
mengenai materi pada buku suplemen dapat menambah wawasan, terbukti dengan hasil persentase sebesar $100 \%$ menandakan bahwa materi yang terdapat pada buku suplemen kimia yang dikembangkan mampu memberikan wawasan untuk pembaca. Maka hal ini sesuai dengan pengertian buku suplemen yaitu dimaksudkan untuk memperkaya wawasan, pengalaman, dan pengetahuan pembacanya (Perbukuan Pusat, 2008, hal. 8). Hasil persentase selanjutnya didapatkan sebesar $83,33 \%$ dengan kategori layak dikarenakan materi sudah mencakup kompetensi dasar (KD), baik dalam ranah kreatifitas yaitu isi materi menunjukkan adanya berbagai cara untuk menyelesaikan masalah, hal ini sesuai dengan tujuan pembelajaran kimia yaitu pembelajaran kimia harus mampu mengembangkan kemampuan peserta didik melakukan penyelidikan dan memecahkan masalah (Firman, 2000, hal. 233). Isi materi memudahkan siswa untuk menghubungkan ilmu pengetahuan dengan kehidupan sehari-hari. Hal ini sesuai dengan penelitian yang dilakukan Esmiyati (2013, hal. 183) bahwa bahan ajar yang dikembangkan memenuhi kriteria wawasan konstekstual dengan menyajikan uraian dan contohcontoh yang sebagian besar disesuaikan dengan kondisi lingkungan terdekat yang sering ditemui dalam kehidupan sehari-hari. Kelayakan didapatkan juga dari persentase hasil sebesar $75 \%$ dari butir pernyataan mengenai ranah proses, hal ini menunjukkan bahwa isi materi memiliki predikat baik dalam menunjukkan proses sains sebagai keterampilan yang dapat digunakan oleh siswa dalam kehidupan sehari-hari. Hasil yang sama terdapat pada ranah sikap menunjukkan bahwa buku suplemen memberikan informasi dan contoh dampak ilmu pengetahuan dan teknologi bagi dirinya dan masyarakat. Karena pada buku menjelaskan materi yang mengajak siswa untuk menyadari adanya dampak negatif dari produk teknologi, peduli pada masyarakat, dan memelihara kelestarian lingkungan (Poedjiadi, 2010, hal. 132). Begitu juga dengan ranah aplikasi menandakan bahwa buku suplemen dapat mengajak siswa agar terlibat dalam perkembangan teknologi untuk pemecahan masalah nyata. Akan tetapi pada butir pernyataan keterlibatan siswa dalam pemecahan isu-isu sosial memiliki persentase sebesar 66,67\%. Hal ini dikarenakan pada buku tidak ada kolom pendapat untuk diisi siswa sesuai dengan karakteristik siswa bahwa tidak ada evaluasi dalam bentuk apapun pada buku suplemen (Pusat Perbukuan, 2008, hal. 65).

Aspek sajian mendapatkan hasil rata-rata persentase aspek sebesar $79,17 \%$ termasuk kategori layak dengan predikat baik. Kelayakan diperoleh dari hasil persentase pada penyajian mudah dipahami, terbukti dengan semua responden guru memberikan hasil sebesar $100 \%$. Selanjutnya kelayakan diperoleh karena buku suplemen dapat memotivasi siswa untuk mencari informasi lebih jauh, hal ini karena buku suplemen yang dikembangkan terdapat kolom berwarna ungu yang berisi pertanyaan seputar materi yang dekat dengan kehidupan siswa, seperti "Apakah gorengan yang Anda makan menggunakan minyak yang digoreng dengan campuran plastik?". Serta dapat memotivasi untuk berkreasi dan berinovasi, contohnya "Cobalah manfaatkan sesuatu disekitar Anda yang dapat dimanfaatkan untuk melestarikan lingkungan agar kita dapat menghirup udara segar". kelayakan selanjutnya didapatkan dari butir pernyataan tentang penyajian yang terstruktur dengan hasil 75\%. Namun hasil persentase sebesar $66,67 \%$ didapatkan pada runtunya penyajian materi dan kelengkapan materi. Hal ini dikarenakan penulis hanya membatasi materi yang dimasukkan kedalam buku suplemen hanya materi yang membahas produk yang sangat sering dipakai oleh masyarakat tanpa tahu cara penggunaan dan dampaknya bagi kesehatan dan lingkungan yaitu plastik, karena sebagaian besar proses pembuatannya melalui reaksi polimerisasi adisi dibandingkan dengan polimerisasi kondensasi.

Data hasil perhitungan persentase respon siswa diperoleh bahwa skor akhir sebesar $82,01 \%$ termasuk kategori layak dengan predikat baik. Berdasarkan hasil respon tersebut diketahui bahwa pada aspek kelayakan isi memenuhi kriteria layak dengan predikat sangat baik dengan rata-rata aspek 
sebesar $85,73 \%$ karena sebagian besar siswa berpendapat bahwa buku suplemen yang dikembangkan dapat menambah pengetahuan untuknya, serta sesuai dengan kondisi dikehidupan siswa sehari-hari dan dapat menyelesaikan masalah yang terjadi di lingkungan sekitarnya. Hal ini sesuai dengan pendapat Sugiyanto, dkk. (2012, hal. 56) bahwa tujuan pendekatan sains teknologi masyarakat adalah untuk menghasilkan siswa yang memiliki bekal pengetahuan agar mampu mengatasi permasalahan yang ada di masyarakat dan mengambil tindakan sesuai dengan keputusan yang diambilnya. Selain itu buku suplemen mampu menunjang pembelajaran.

Kelayakan buku suplemen berdasarkan respon siswa juga didapatkan melalui aspek grafika sebesar $84,48 \%$. Hasil respon siswa menunjukkan bahwa desain buku suplemen kimia yang dikembangkan menarik untuk dipelajari. Hasil yang sama juga didapatkan oleh penelitian yang dilakukan Esmiyati (2013, hal. 128) bahwa siswa menyukai modul yang dikembangkan dan tertarik untuk mempelajarinya. Penggunaan jenis dan ukuran huruf yang digunakan dalam buku suplemen menarik dan konsisten pada semua bagian buku. Ilustrasi yang digunakan dalam buku suplemen menarik untuk dilihat. Hal ini sesuai dengan pendapat Fajar dalam (Esmiyati, 2013, hal. 184) bahwa belajar memerlukan minat dan perhatian siswa. Serta ilustrasi yang digunakan dapat membantu pemahaman materi, sehingga memudahkan siswa untuk memahaminya.

Pada aspek sajian didapatkan persentase rata-rata aspek sebesar $78,86 \%$. Hal ini menandakan bahwa buku suplemen yang dikembangkan runtut dan terstruktur. selain itu buku suplemen memiliki predikat baik dalam memotivasi siswa untuk mencari informasi lebih jauh serta mampu memotivasi untuk berkreasi dan berinovasi. Karena penyajian pada buku suplemen ini terdapat beberapa pertanyaan yang berhubungan dengan kehidupan sehari-hari. Dari aspek bahasa, penulisan buku suplemen sudah sesuai dengan kaidah EYD dan dikategorikan bahwa bahasa yang digunakan termasuk predikat baik yaitu mampu untuk dimengerti siswa sehingga siswa merasa lebih mudah mempelajarinya, bahkan hasil ini melampaui penelitian yang dilakukan Saputra (2015, hal 145) yang mendapatkan kategori cukup baik.

Buku suplemen kimia polimer yang dikembangkan memiliki karakteristik sebagai berikut: pertama: Berbasis sains teknologi masyarakat, yaitu mengintegrasikan dengan ranah-ranah sains teknologi masyarakat yang terdiri atas ranah konsep, proses, sikap, kreativitas, aplikasi dan keterkaitan. Contohnya dapat dilihat pada gambar 2 sampai gambar 4.

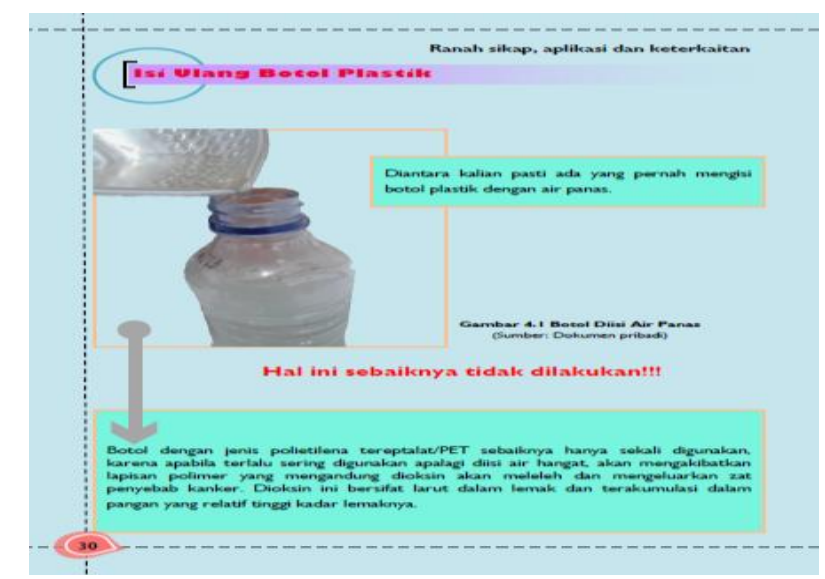

Gambar 2. Contoh Penerapan Ranah Konsep

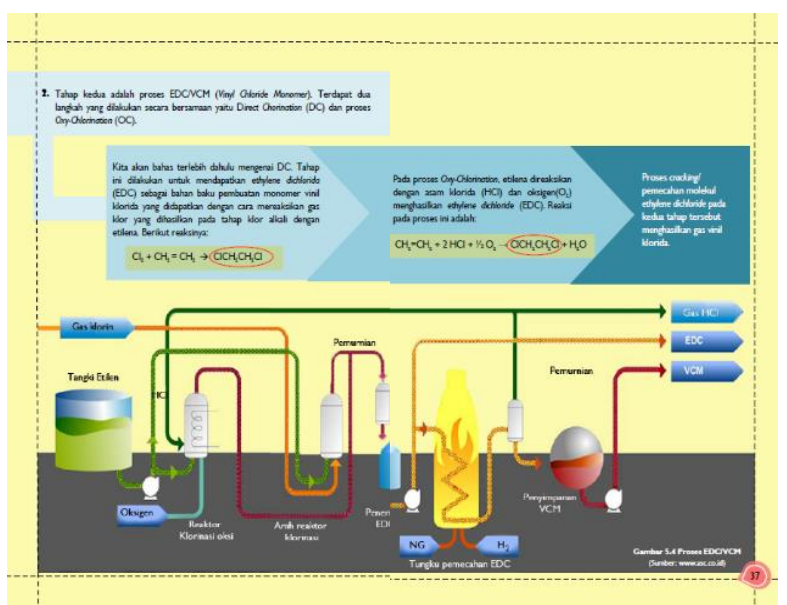

Gambar 3. Contoh Penerapan Ranah Proses 


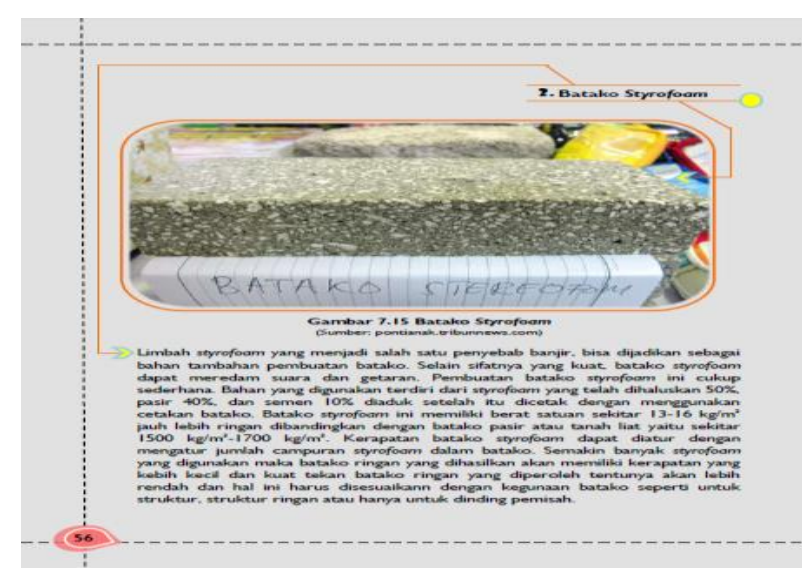

\section{Gambar 3. Contoh Penerapan Ranah Kreativitas}

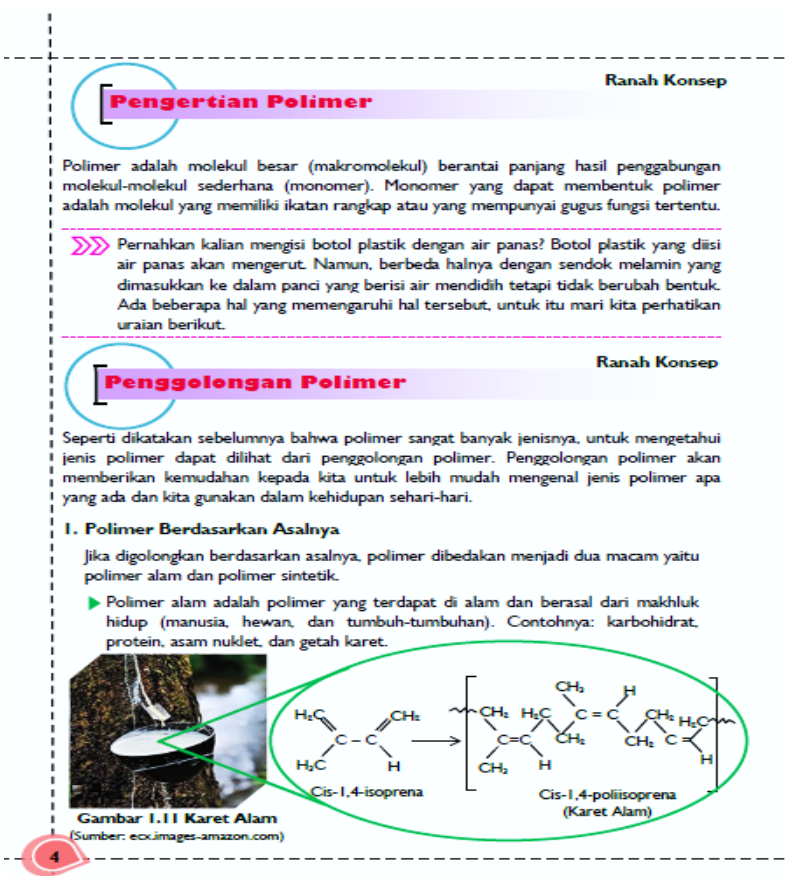

Gambar 4. Contoh Penerapan Ranah Sikap

Kedua: Di awal buku, terdapat uraian mengenai kode-kode plastik agar pembaca termotivasi untuk membaca info/materi lebih jauh mengenai kode-kode plastik tersebut di bab selanjutnya. Ketiga: Disetiap awal bab, diuraikan terlebih dahulu isu-isu atau permasalahan yang sedang hangat dibicarakan di masyarakat agar pembaca lebih peduli mengenai lingkungan tempat tinggalnya sehingga pembaca akan merasakan bahwa ilmu kimia berhubungan erat dengan kehidupannya sehari-hari.
Keempat: Penyajian materi antara konsep dan aplikasi serta dampaknya disajikan secara seimbang dengan mengintegrasikan ranah sains teknologi masyarakat yaitu ranah konsep terdapat pada penemuan-penemuan jenis polimer. Ranah proses terdapat pada proses pembuatan produk dari bahan baku polimer. Ranah sikap terdapat pada tips-tips penggunaan dan tindak lanjut setelah pembaca mengetahui dampak dari penggunaan produk polimer. Ranah kreativitas terdapat pada materi tentang produk baru yang dihasilkan oleh seseorang sehingga produk tersebut dapat digunakan untuk mencukupi kebutuhan masyarakat atau menanggulangi dampak negatif dari polimer. Ranah aplikasi dan keterkaitan terdapat pada contoh-contoh kegunaan polimer di kehidupan sehari-hari.

\section{KESIMPULAN}

Proses pengembangan buku suplemen kimia berbasis sains teknologi masyarakat pada materi kimia polimer ini terdiri atas tiga tahap, yaitu: tahap perancangan menghasilkan indikator buku suplemen kimia yang telah diintegrasikan dengan lima ranah STM (ranah konsep, proses, sikap, kreativitas, aplikasi dan keterkaitan) dan desain buku suplemen yang kemudian dijadikan acuan dalam mengembangkan buku suplemen. Tahap produksi menghasilkan buku suplemen yang kemudian divalidasi dan direvisi sehingga dihasilkan buku suplemen final. Tahap evaluasi ialah tahap untuk memperoleh data respon atau penilaian guru dan siswa terhadap buku suplemen kimia berbasis sains teknologi masyarakat pada materi kimia polimer. Karakteristik buku suplemen kimia berbasis sains teknologi masyarakat pada materi kimia polimer yang dikembangkan yaitu di awal buku, terdapat uraian mengenai kode-kode plastik agar pembaca termotivasi untuk membaca info/materi lebih jauh mengenai kode-kode plastik tersebut di bab selanjutnya. Disetiap awal bab, diuraikan terlebih dahulu isu-isu atau permasalahan yang sedang hangat dibicarakan di masyarakat agar pembaca lebih peduli mengenai lingkungan tempat tinggalnya sehingga pembaca akan 
merasakan bahwa ilmu kimia berhubungan erat dengan kehidupannya sehari-hari. Penyajian materi antara konsep dan aplikasi serta dampaknya disajikan secara seimbang dengan mengintegrasikan ranah sains teknologi masyarakat yaitu ranah konsep terdapat pada penemuan-penemuan jenis polimer. Ranah proses terdapat pada proses pembuatan produk dari bahan baku polimer. Ranah sikap terdapat pada tips-tips penggunaan dan tindak lanjut setelah pembaca mengetahui dampak dari penggunaan produk polimer. Ranah kreativitas terdapat pada materi tentang produk baru yang dihasilkan oleh seseorang sehingga produk tersebut dapat digunakan untuk mencukupi kebutuhan masyarakat atau menanggulangi dampak negatif dari polimer. Ranah aplikasi dan keterkaitan terdapat pada contoh-contoh kegunaan polimer di kehidupan sehari-hari. Adapun persentase total skor respon guru sebesar $80,61 \%$ termasuk dalam kategori layak dengan predikat baik dan respon siswa mendapatkan total skor sebesar $82,01 \%$ termasuk dalam kategori layak dengan predikat baik.

\section{DAFTAR PUSTAKA}

Binadja, Achmad, \& Nuryanto. (2010). Efektivitas Pembelajaran Kimia dengan Pendekatan Salingtemas ditinjau dari Minat dan Hasil Belajar Siswa. Jurnal Inovasi Pendidikan Kimia, Vol. 4, No. 1, 552-556.

Direktorat Pembinaan SMA. (2010). Juknis Pengembangan Bahan Ajar SMA. 25-35.

Firman, H. (2000). Pendidikan Kimia. In F.-U. Tim Pengembang Ilmu Pendidikan, Ilmu dan Aplikasi Pendidikan Bagian III (pp. 221-241). Bandung: PT. Imtima.

Fitri, Z. (2013). Penerapan Pendekatan Sains Teknologi Masyarakat (STM) pada Materi Koloid di MAN Kuto Baro Aceh Besar. CDA vol.1 No. 1, 41-47.

Hervici, Vany Fahreza. (2013). Pengembangan Modul Kimia Polimer Berbasis Kontekstual Sebagai Sumber Belajar Mandiri Peserta Didik SMA/MA Kelas XII Semester 2. (Skripsi). Universitas Islam Negeri Sunan Kalijaga, Yogyakarta.
Jannah, D. F., \& Dwiningsih, K. (2013). Kelayakan Buku Ajar Kimia Berorientasi Quantum Learning pada Materi Kimia Unsur untuk kelas XII SMA. Unesa Journal of Chemical Education Vol. 2, No. 2 ISSN 2252-9454, 163-170.

Kurniasari, D. A. (2014). Pengembangan Buku Suplemen IPA Terpadu dengan Tema Pendengaran Kelas VIII. Unnes Science Education Journal 3 (2), 463.

Margono. (2013). Metodelogi Penelitian Kualitatif. Jakarta: Rineka Cipta.

MenLHK. (2016, Februari 09). siaran-31menuju-penerapan-kebijakan-kantong-

plastik-berbayar.html. Dipetik Maret 19, 2016, dari www.menlhk.go.id: www.menlhk.go.id/siaran-31-menujupenerapan-kebijakan-kantong-plastikberbayar.html

Menteri Pendidikan Nasional Republik Indonesia Nomor 2 Tahun 2008. (2008). Buku. Jakarta: Menteri Pendidikan Nasional.

Najid, Annisah. (2015). Pengembangan Buku Suplemen Kimia Berbasis Kearifan Lokal Kota Tangerang. (Skripsi). Universitas Islam Negeri Syarif Hidayatullah, Jakarta

Nugraheni, Dian. (2013). Pembelajaran Bervisi dan Berpendekatam SETS terhadap Prestasi Belajar ditinjau dari Kemampuan Berpikir Kritsis Siswa Kelas X SMAN 2 Sukoharjo pada Materi Minyak Bumi. Jurnal Pendidikan Kimia, vol.2 no.3.

Nurlaelasari, Lela. (2015, Agustus 10). Wawancara Analisis Kebutuhan. (M. Rizki, Pewawancara)

Paembonan, Taya. (1990). Penerbitan dan Pengembangan Buku Pelajaran di Indonesia. Jakarta: Pusat Perbukuan Departemen Pendidikan dan Kebudayaan.

Peraturan Pemerintah Nomor 16 Tahun 2007. (2007). Standar Kompetensi Guru. Jakarta: Departemen Pendidikan Nasional.

Peraturan Menteri Pendidian dan Kebudayaan Nomor 69 Tahun 2013. (2013). Kerangka Dasar dan Struktur Kurikulum Sekolah Menengah Atas/ Madrasah Aliyah. Jakarta: Menteri Pendidikan dan Kebudayaan.

Permendiknas. (2010). Panduan Pengembangan Bahan Ajar. Jakarta: Direktorat Pembinaan Sekolah Menengah Atas. 
Poedjiadi, Anna. (2010). Sains Teknologi Lingkungan. Bandung: PT Remaja Rosdakarya.

Pusat Perbukuan. (2014). Instrumen Penilaian Buku Pengayaan Pengetahuan. Instrumen B1.

Pusat Perbukuan. (2008). Pedoman Penulisan Buku Nonteks. Jakarta: Departemen Pendidian Nasional.

Riduwan. (2010). Dasar-Dasar Statistika. Bandung: Alfabeta.

Riyanto, A. (2013). Pengembangan Buku Pengayaan Keterampilan Membaca Bahasa Indonesia yang Bermuatan Niai Kewirausahaan. SELOKA 2 (1).

Saefudin, E. (2015, Agustus 10). Wawancara Analisis Kebutuhan. (M. Rizki, Pewawancara)

Sanjaya, Wina. (2013). Penelitian Pendidikan: Jenis, Metode, dan Prosedur. Jakarta: Kencana.

Setiawan, Denny. (2007). Pengembangan Bahan Ajar. Jakarta: Universitas Terbuka.

Sugiyanto, Kartika, I., \& Purwanto, J. (2012). Pengembanagn Modul IPA Terpadu Berbasis Sains teknologi Masyarakat dengan Tema Tekonologi Biogas. Jurnal Kependidikan, Volumr 42, Nomor 1, Halaman 54-60.

Sugiyono. (2013). Metode Penelitian Pendidian: Pendekatan Kuantitatif, Kualitatif, dan R\&D. Bandung: Alfabeta.

Teti. (2015, Agustus 06). Wawancara Analisis Kebutuhan. (M. Rizki, Pewawancara).

Tirtaraharja, U. (2008). Pengantar Pendidikan. Jakarta: Rineka Cipta.

Undang-Undang Republik Indonesia Nomor 20 Tahun 2003. (2003). Sistem Pendidikan Nasional. Jakarta: Departemen Pendidikan Nasional.

Ulfa, Anik, dkk. (2013). Pengembangan LKS IPA Berbasis Word Square Model Keterpaduan Connected. Unnes Science Educatoin journal, 2.

Widodo, C. S. (2008). Panduan Menyusun Bahan Ajar Berbasis Kompetensi. Jakarta: PT Alex Media Komputindo.

Zul, Nurlita. (2015, Agustur 10). Wawancara Analisis Kebutuhan. (M. Rizki, Pewawancara). 